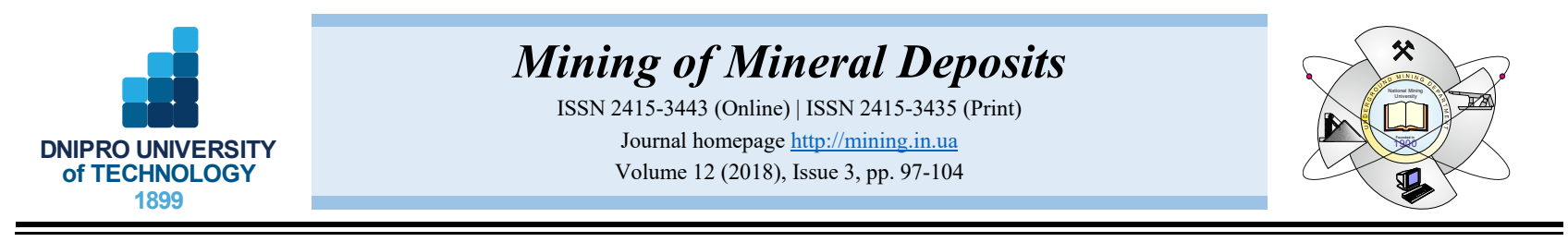

UDC 551.481.16

https://doi.org/10.15407/mining12.03.097

\title{
OPTIMIZATION OF SALT CRYSTALLIZATION PROCESS BY SOLAR ENERGY WITH THE USE OF MIRROR REFLECTION, CASE OF CHOTT MEROUANE EL-OUED (SOUTH EAST OF ALGERIA)
}

\author{
S. Remli ${ }^{1,2}$, M. Bounouala ${ }^{1}$, I. Rouaiguia ${ }^{1}$, A. Benselhoub ${ }^{3 *}$

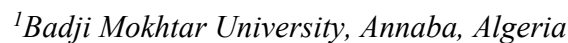 \\ ${ }^{2}$ Université Larbi Tébessi, Tébessa, Algeria \\ ${ }^{3}$ State Agrarian and Economic University, Dnipro, Ukraine \\ *Corresponding author: e-mail benselhoub@yahoo.fr, tel. +213561414652
}

\begin{abstract}
Purpose. This paper aims to improve the harvesting conditions of the crystallized salt layer of the Salins Merouane El Meghaier (SME) - South East of Algeria, by creating favorable conditions for means of harvesting (harvesters), thanks to the acceleration of evaporation-crystallization process of salt by using an installation of flat mirrors, which reflect solar radiation towards the evaporating surface.
\end{abstract}

Methods. To achieve the objectives, a stall installation contains pans equipped with different mirror surfaces. Compared with other designs, this test unit is installed near the Chott during the months of December and January.

Findings. The optimization rate of salt evaporation-crystallization process depends on the surface of the reflection mirror used, which allows obtaining a layer of soft salt easy to harvest during the winter months.

Originality. The use of mirrors reflecting solar radiation in salt pans of the unit in Salins Merouane El Meghaier enables to improve the salt exploitation conditions in quantitative, qualitative and economic terms, and to minimize the occupation of agriculture area.

Practical implications. The exploitation of solar energy for salt production at the unit in Salins Merouane El Meghaier represents a free source, which is inexhaustible and produces no harmful impact on the environment.

Keywords: El-Oued, lake Merouane, solar energy, optimization, evaporation, crystallization, salts

\section{INTRODUCTION}

Solar energy, which is characterized by a lack of pollution and its availability, has attracted much attention in recent years. Operating systems that utilize this form of energy require little maintenance and have a good operating reliability, increasing autonomy, extreme resistance to natural conditions (temperature, humidity, wind, corrosion, etc.), and therefore a long service life. It therefore appears that solar energy can provide real solutions to the various problems that currently arise with regard to climate change, energy crises (Yettou, Malek, Haddadi, \& Gama1, 2009).

Kasedde, Lwanyaga, Kirabira, \& Bäbler, (2015) conducted analysis of literature describing experimental studies and modeling oriented towards the use of solar energy to improve evaporation of brine. Abdel-Aal \& Al-Naafa (1993) studied the increased evaporation of salt water in multi-purpose solar desalination units using flat-plate solar collectors. Their results showed that the contribution of concentrated solar energy was estimated to be 3.5 times that of the direct solar flux allowing the separation of soluble inorganic salts such as $\mathrm{NaCl}, \mathrm{MgCl}_{2}$ and the others. Zhang, Ge, Li, \& Li (1993) presented a simulation model for the evaporation of brine by solar radiation for salt production where the various parameters involved in the behavior of the salt table were analyzed. Huang, Shi, \& Ge (1999) studied the effect of a black insulating sheet on the rate of evaporation from a shallow salting table. The results proved that the rate of saline table evaporation increased by $10 \%$. In another attempt, Tamimi \& Rawajfeh (2007) modeled the thermal performance of solar evaporation basins loaded with the Dead Sea water. The model demonstrated that the efficiency of a solar evaporator is limited by the optical absorption capacity of saline water as the upper limit. Zeng et al. (2011) develop ed a strategy for improving solar evaporation using magnetic particles absorbing floating light. In their survey, evaporation was improved by a factor of 2.3 in solar evaporation of $3.5 \%$ water. Diaz, Stewart, \& Brownson (2012) provide an analysis using concentrated solar thermal energy systems to assess the increased

(C) 2018. S. Remli, M. Bounouala, I. Rouaiguia, A. Benselhoub. Published by the Dnipro University of Technology on behalf of Mining of Mineral Deposits. This is an Open Access article distributed under the terms of the Creative Commons Attribution License (http://creativecommons.org/licenses/by/4.0/), which permits unrestricted reuse, distribution, and reproduction in any medium, provided the original work is properly cited. 
efficiency of sea salt production in southern Spain. The conclude that the improved system could evaporate water six to ten times faster than the natural evaporation process. More recently, Horri, Nan, Chen, \& Wang (2014) modeled the floating solar evaporation process assisted by light absorbing materials. The model shows that the evaporation rate can be improved by approximate factors of $2.3,2$ and 1.8 when using $0.045,0.023$, and $0.015 \mathrm{~g}$ of light absorbing material, respectively.

The objective of the present study is to optimize the crystallization process at the lake Merouane unit (National company) in El Meghaier, in order to adjust the quantitative and qualitative plan according to the needs of the market. It is based on the acceleration of evaporation speed using solar energy harnessed in the installation of planar mirrors which is designed to capture the solar radiation and reflect it towards the surface of the brine (Bounouala, Remli, \& Talhi, 2015).

\section{GEOGRAPHICAL SITUATION AND HYDRO- GEOLOGY OF THE CHOTT MEROUANE}

Chott Melghair $\left(34^{\circ} 15^{\prime} \mathrm{N}, 06^{\circ} 17^{\prime} \mathrm{E}\right)$ and Chott Merouane $\left(3410.63^{\prime} \mathrm{N}, 6^{\circ} 17.32^{\prime} \mathrm{E}\right)$ are the largest salt lakes in Algeria. These Chotts are located in the northeast of the northern Sahara and are part of the Melghair Chott basin in south-eastern Algeria covering large area of 551500 ha to 337700 ha. The altitude of these Chotts is considered to be the lowest in northern Africa, and in some places is $31 \mathrm{~m}$ below sea level. The Melgair Merouane Chotts constitute a vast strip that extends from southern Tunisia to the Atlas Mountain in northern Algeria (Mahowald, Bryant, del Corral, \& Steinberger, 2003).

Evaporation of the Chotts, especially during the dry season, gives rise to salt crystals composed mainly of sodium chloride, from 0 to $10 \mathrm{~cm}$ big, which makes the zone an important source of salt mineral. Other minerals identified on the surface of the Chotts include gypsum, calcite, and clays (Hacini, Kherici, \& Oelkers, 2008).

Due to the combined effect of evaporation and incoming water, the Merouane Chott experiences annual cycles of lake filling and complete evaporation. It is fed by three main water sources, namely the Oued Righ Canal, which also drains local urban water, groundwater from the terminal complex aquifer and precipitation (Fig. 1) (Hacini, Kherici, \& Oelkers, 2008).

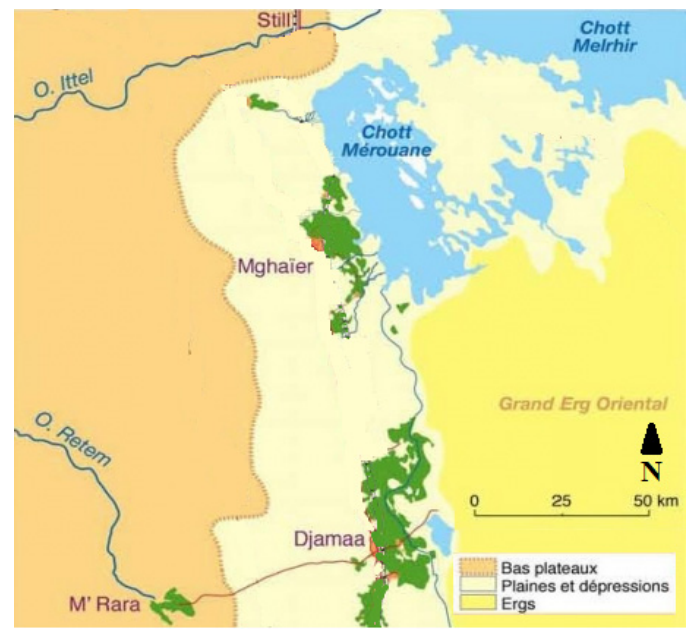

Figure 1. Supply source of Chott Merouane (Ballais, 2010)
The $150 \mathrm{~km}$ long canal drains the waters up to Chott Merouane. The total amount of water drained through the Oued Righ Canal was estimated at $131.5 \times 10^{6} \mathrm{~m}^{3}$ in 1994 (Hacini, Kherici, \& Oelkers, 2008). It is fed, according to Ballais (2010), by collector water from baths and oases.

The annual share of the groundwater supplying Chott Merouane was estimated at $62 \times 10^{6} \mathrm{~m}^{3}$ (Unesco, 1972). While the contribution of precipitation, according to Hacini, Kherici, \& Oelkers (2008), to the water supply of the Chott was estimated by the meteorological station of Touggourt at $4.9 \times 10^{6} \mathrm{~m}^{3}$.

\section{MATERIALS AND METHODS}

\subsection{Studies of Chott Merouane climatic parameters}

Through a series of observations of the climatic parameters of Chott Merouane (1975-2010), we can establish the following patterns of natural physiochemical conditions impact (Fig. 2):

- average monthly evaporation (Fig. 2a) occurs according to a simple pattern, showing decrease towards the winter season and increase approaching the summer season; this fluctuation of evaporation is governed by the temperature variation (Enasel, 2011);

- average monthly precipitation (Fig. $2 \mathrm{~b}$ ) shows that January is the most watered month with $19.14 \mathrm{~mm}$ and July is the driest month with $0.87 \mathrm{~mm}$;

- average monthly temperature (Fig. 2c) shows that July is the hottest month, with recorded $33.50^{\circ} \mathrm{C}$, and January is the coldest month with average temperature of $10.30^{\circ} \mathrm{C}$. The influence of temperature on the brine chemical quality is felt during the summer period, when we observed concentration of elements resulting from evaporation;

- wind speed (Fig. 2d) is stable at about $3 \mathrm{~m} / \mathrm{s}$, except for two months (March, July), when it increased from 3.31 to $4.13 \mathrm{~m} / \mathrm{s}$;

- the humidity of the air (marked by two distinct periods - Figure 2e). Thus, the period from October to February is relatively humid, with more than $50 \%$ humidity, growing from $51.69 \%$ to a maximum of $65.85 \%$ in December. The period from March to September is dry, with humidity decreasing to a minimum of $34 \%$ in August;

- the duration of insolation (the region receives a very high amount of sunlight during all months of the year (Fig. 2f), with a maximum of about 358 hours in July and a minimum of 229 hours in January (Enasel, 2011).

\subsection{The solar radiation of El Oued region}

El Oued region is characterized by a high level of solar potential. As shown in Figure 3, this region receives an average amount of annual solar radiation at $4.85 \mathrm{kWh} / \mathrm{m}^{2}$ with a total insolation period of $3900 \mathrm{~h} /$ year.

It can be seen that in winter the region obtains less solar energy with the average daily solar radiation varying between 3.17 and $3.77 \mathrm{~kW} \mathrm{~h} / \mathrm{m}^{2}$. Solar energy amount becomes very high between April and September, when the average daily solar radiation varies from 4.93 to $7.54 \mathrm{kWh} / \mathrm{m}^{2}$ (Hadj Ammar, Benhaouaet, \& Balghouthi, 2015). 
(a)

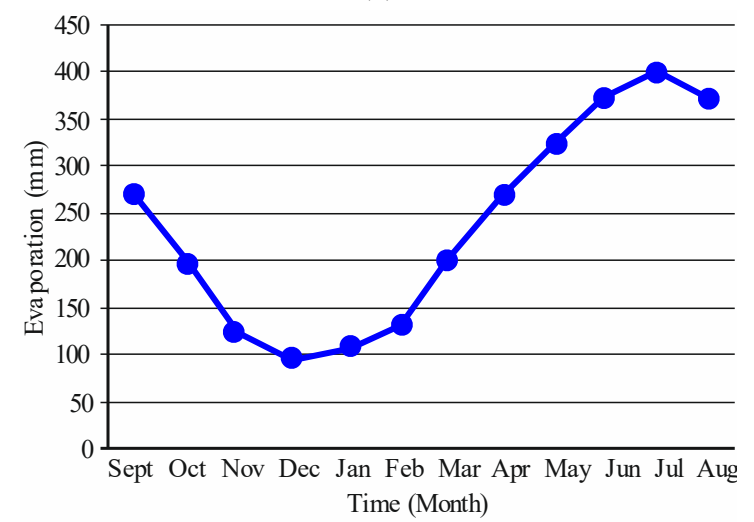

(c)

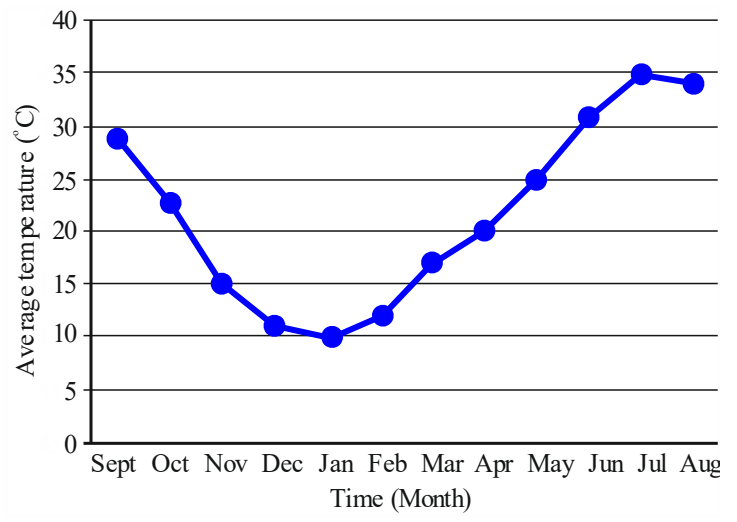

(e)

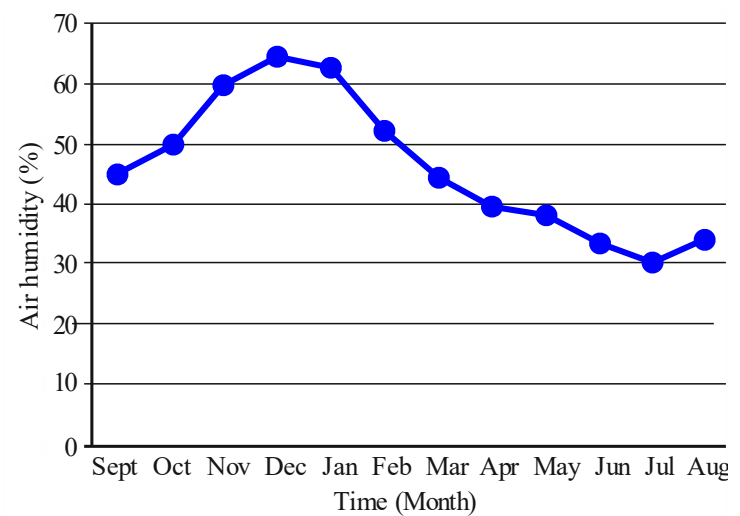

(b)

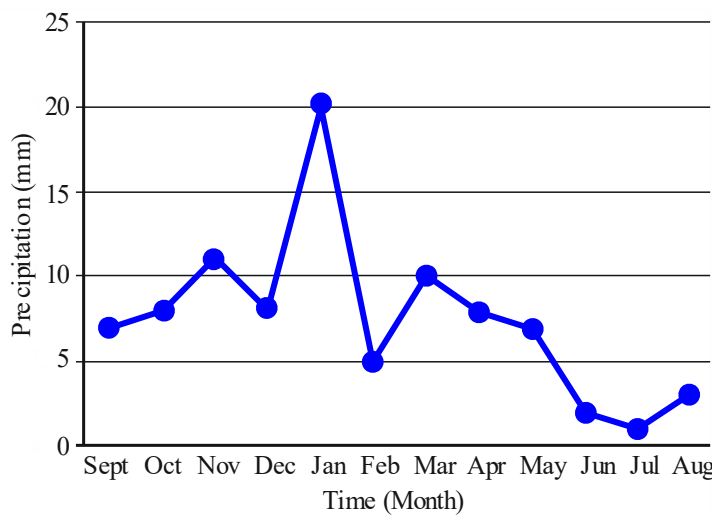

(d)

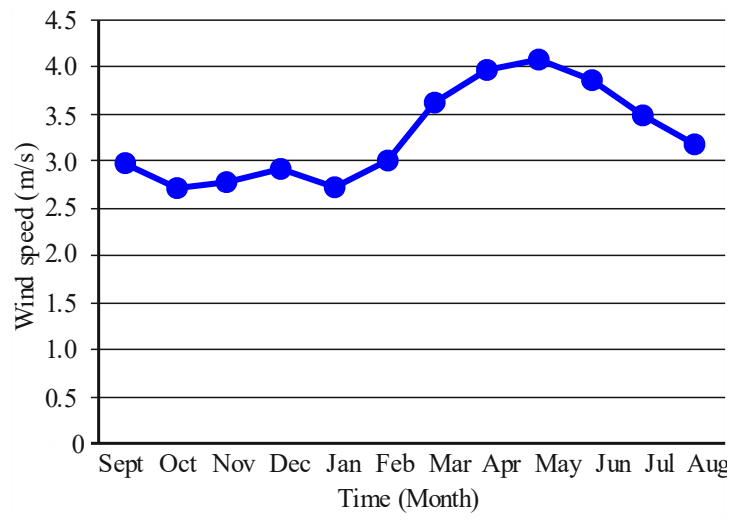

(f)

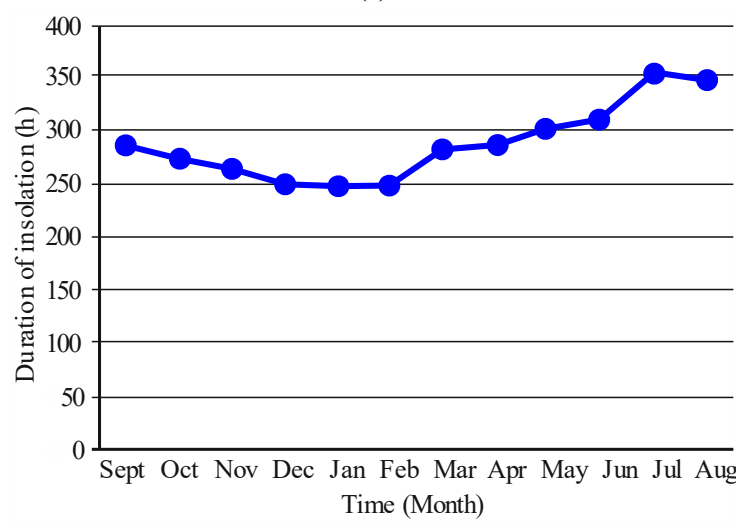

Figure 2. Observations of Chott Merouane climatic parameters (1975-2010): (a) evaporation; (b) precipitation of water; (c) temperature; (d) wind speed; (e) air humidity; (f) duration of insolation

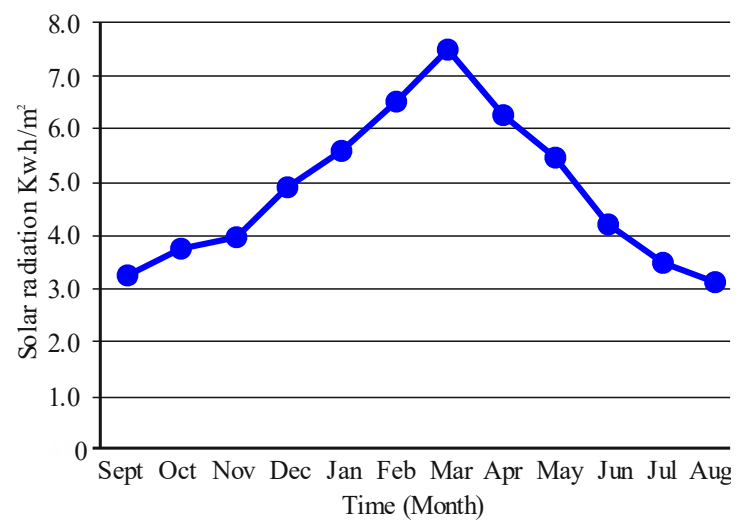

Figure 3. Solar radiation throughout the year 2015 in El Oued region

\subsection{Experimentation}

In the present study, the test was conducted during December and January of 2016-2017.This period represents the first filling of the Chott by the brine. The test started on 12.12.2016 and lasted to 01.02.2017. The five plastic pans under observation (Fig. 4) were buried in the ground to avoid heating of their external walls by solar radiation.

They were installed near the Chott Merouane and filled by brine with a thickness of $120 \mathrm{~mm}$ each. Two pans P1 and P2 were equipped with flat simple mirrors (31.49\% of the brine surface for SM and $77 \%$ of the brine surface for GM1), while the third was a control pan $\mathrm{P} 0$, with installed mirrors capturing the sun rays and reflecting them towards the surface of the brine. 


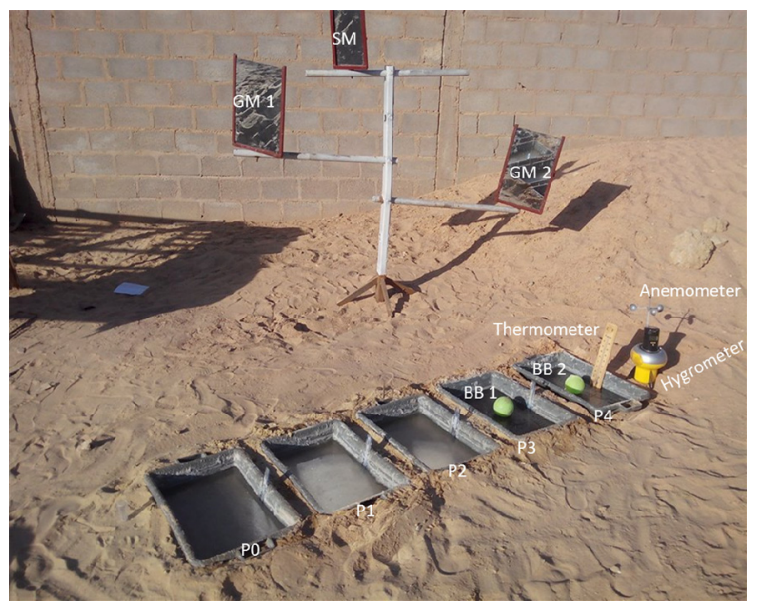

Figure 4. Photograph of the experimental brine pans on Chott Merouane-El Oued

From 09:00 in the morning until 16:00 in the evening, the mirrors followed the movement of the sun by manual adjustment of their angles to the sun position (azimuth and elevation) Figure 5.

During the test period, we conducted daily measurements of wind speed, humidity and especially evaporation in $\mathrm{mm}$, which was done using the ruler fixed in the wall of each pan (Evaporation = the thickness of the brine yesterday - the thickness of today's brine).

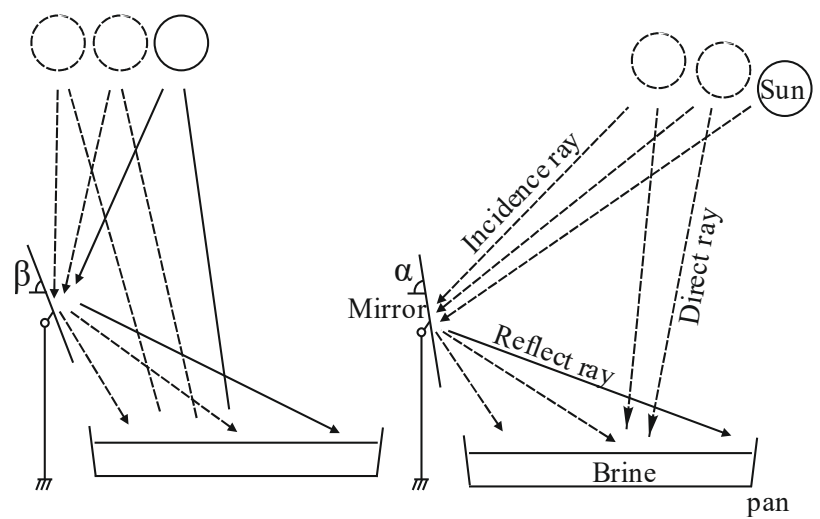

Figure 5. Projection of solar radiation towards the pan

In this work, we present the results for the control pan $\mathrm{P} 0$, and those with large and small mirrors - P1 and P2. The other results for B3 and B4 pans will be studied later (Table 1).

Table 1. Pans equipment

\begin{tabular}{ccccc}
\hline \multirow{2}{*}{ Brine Pan } & $\begin{array}{c}\text { With } \\
\text { large } \\
\text { mirror } \\
\end{array}$ & $\begin{array}{c}\text { With } \\
\text { small } \\
\text { mirror } \\
\text { GM }\end{array}$ & $\begin{array}{c}\text { With } \\
\text { black } \\
\text { body } \\
\text { BB1 }\end{array}$ & $\begin{array}{c}\text { With black } \\
\text { body }+ \\
\text { large mirror } \\
\text { BB2 + GM2 }\end{array}$ \\
\hline P0 (Control) & & & & \\
P1 & & & & \\
P2 & & & & \\
P3 & & & & \\
P4 & & & & \\
\hline
\end{tabular}

Measurement equipment: densimeter, hygrometer, rain gauge, anemometer, thermometer. Sizing of the used equipment is shown in Table 2.
Table 2. Sizing of the equipment used

\begin{tabular}{lcc}
\hline \multicolumn{1}{c}{ Designation } & Dimension, $\mathrm{m}$ & Area, $\mathrm{m}^{2}$ \\
\hline P0, P1, P2, P3, P4 & $0.55 \cdot 0.34$ & 0.1870 \\
SM & $0.31 \cdot 0.19$ & 0.0589 \\
GM1, GM2 & $0.48 \cdot 0.30$ & 0.1440 \\
BB1, BB2 & $0.46 \cdot 0.26$ & 0.1190 \\
\hline
\end{tabular}

Chemical analysis of the brine taken from Chott Merouane showed that the concentration of the halite is important when it reaches $313.304 \mathrm{~g} / 1$ (Table 3).

Table 3. Brine chemical analysis

\begin{tabular}{cccccccc}
\hline $\begin{array}{c}\text { Place of Density } \\
\text { sampling }\end{array}$ & $\begin{array}{c}\mathrm{Ca}^{+2} \\
(\mathrm{Bé})\end{array}$ & $\begin{array}{c}\mathrm{Mg}^{+2} \\
(\mathrm{~g} / \mathrm{l})\end{array}$ & $\begin{array}{c}\mathrm{So}^{-2} \\
(\mathrm{~g} / \mathrm{l})\end{array}$ & $\begin{array}{c}\mathrm{HCO}_{3}{ }^{-} \\
(\mathrm{g} / \mathrm{l})\end{array}$ & $\begin{array}{c}\mathrm{Cl}^{-} \\
(\mathrm{g} / \mathrm{l})\end{array}$ & $\begin{array}{c}\mathrm{NaCl}^{-} \\
(\mathrm{g} / \mathrm{l})\end{array}$ \\
\hline $\begin{array}{c}\text { Chott } \\
\text { Merouane }\end{array}$ & 23.6 & 1.252 & 8.36 & 18.727 & 7.625 & 190.812 & 313.304 \\
\hline
\end{tabular}

\section{RESULTS AND DISCUSSION}

Daily monitoring of the test yielded the results presented in Table 4. The thickness curves of the brine and crystallized salt in the mirror pans suggest that there is a relatively small difference between them, with respect to the difference in the surfaces between the mirrors Figure 6.

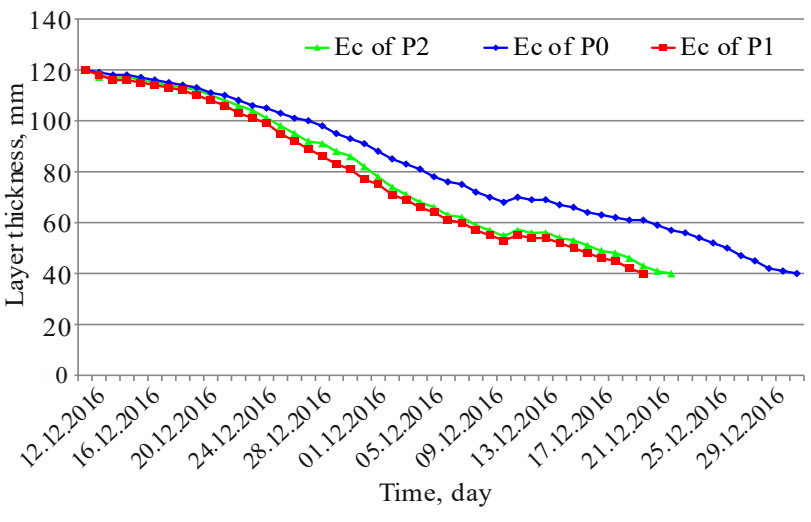

Figure 6. Layer thickness curves (salt + brine) of P0, P1 and P2

The spacing of these curves in comparison with the brine and crystallized salt curve of the control pan increases with time until the final crystallization of salt (formation of a crystallized layer $40 \mathrm{~mm}$ thick). We also observed an increase in thicknesses of $2 \mathrm{~mm}$ during the day 11.01.2017 caused by precipitation of rain $(2.5 \mathrm{~mm})$.

From the measurements taken during the test, the average wind speed is $1.13 \mathrm{~m} / \mathrm{s}$ and the average humidity is $36 \%$. The excess temperature generated by the reflection of the solar rays thanks to the plane mirrors directed towards the brine surface in the two pans appeared in the curves (Fig. 7) due to the increase in the evaporation rate of about $1 \mathrm{~mm} /$ day compared to that of the control pan.

The amount of water in the brine of P1 and P2 is sufficient to stop evaporation on 21.01.2017 and 23.01.2017, on the other hand, evaporation in the control pan P0 continues until 01.02.2017.

Thus, formation of a crystallized salt layer suitable for harvesting with a thickness of $40 \mathrm{~mm}$ in each pan took 52 days for $\mathrm{P} 0$ and 41, 43 days for $\mathrm{P} 1, \mathrm{P} 2$ respectively. 
Table 4. Daily monitoring of the layer thickness (brine + crystallized salt), evaporation, precipitation and meteorological observation

\begin{tabular}{|c|c|c|c|c|c|}
\hline \multirow[t]{2}{*}{$\begin{array}{l}\text { No. } \\
\text { of } \\
\text { day }\end{array}$} & \multirow[t]{2}{*}{ Data } & $\begin{array}{c}\text { Thickness of } \\
\text { layer (brine }+ \\
\text { crystallized } \\
\text { salt) }(E c, \mathrm{~mm})\end{array}$ & $\begin{array}{l}\text { Evaporation } \\
(E, \mathrm{~mm})\end{array}$ & \multirow[t]{2}{*}{$\begin{array}{c}\text { Pre- } \\
\text { cipita- } \\
\text { tion } \\
-(\mathrm{mm})\end{array}$} & \multirow[t]{2}{*}{$\begin{array}{l}\text { Meteor- } \\
\text { ological } \\
\text { observa- } \\
\text { tion* }\end{array}$} \\
\hline & & $\begin{array}{lll}\text { P0 } & \text { P2 } & \text { P1 }\end{array}$ & $\begin{array}{lll}\text { P0 } & \text { P2 } & \text { P1 }\end{array}$ & & \\
\hline
\end{tabular}

\begin{tabular}{|c|c|c|c|c|c|c|c|c|c|}
\hline 1 & 12.12 .16 & 120 & 120 & 120 & - & - & - & - & - \\
\hline 2 & 13.12 .16 & 119 & 118 & 118 & 1 & 2 & 2 & 0 & 1 \\
\hline 3 & 14.12 .16 & 118 & 117 & 116 & 1 & 1 & 2 & 0 & 2 \\
\hline 4 & 15.12 .16 & 118 & 117 & 116 & 0 & 0 & 0 & 0 & 2 \\
\hline 5 & 16.12 .16 & 117 & 116 & 115 & 1 & 1 & 1 & 0 & 2 \\
\hline 6 & 17.12 .16 & 116 & 115 & 114 & 1 & 1 & 1 & 0 & 1 \\
\hline 7 & 18.12 .16 & 115 & 114 & 113 & 1 & 1 & 1 & 0 & 2 \\
\hline 8 & 19.12 .16 & 114 & 113 & 112 & 1 & 1 & 1 & 0 & 2 \\
\hline 9 & 20.12 .16 & 113 & 112 & 110 & 1 & 1 & 2 & 0 & 1 \\
\hline 10 & 21.12 .16 & 111 & 110 & 108 & 2 & 2 & 2 & 0 & 1 \\
\hline 11 & 22.12 .16 & 110 & 108 & 106 & 1 & 2 & 2 & 0 & 1 \\
\hline 12 & 23.12 .16 & 108 & 106 & 103 & 2 & 2 & 3 & 0 & 1 \\
\hline 13 & 24.12 .16 & 106 & 104 & 101 & 2 & 2 & 2 & 0 & 1 \\
\hline 14 & 25.12 .16 & 105 & 101 & 99 & 1 & 3 & 2 & 0 & 1 \\
\hline 15 & 26.12 .16 & 103 & 98 & 95 & 2 & 3 & 4 & 0 & 1 \\
\hline 16 & 27.12 .16 & 101 & 95 & 92 & 2 & 3 & 3 & 0 & 1 \\
\hline 17 & 28.12 .16 & 100 & 92 & 89 & 1 & 3 & 3 & 0 & 1 \\
\hline 18 & 29.12 .16 & 98 & 91 & 86 & 2 & 1 & 3 & 0 & 1 \\
\hline 19 & 30.12 .16 & 95 & 88 & 83 & 3 & 3 & 3 & 0 & 1 \\
\hline 20 & 31.12 .16 & 93 & 86 & 81 & 2 & 2 & 2 & 0 & 1 \\
\hline 21 & 01.01 .17 & 91 & 82 & 77 & 2 & 4 & 4 & 0 & 1 \\
\hline 22 & 02.01 .17 & 88 & 78 & 75 & 3 & 4 & 2 & 0 & 1 \\
\hline 23 & 03.01 .17 & 85 & 74 & 71 & 3 & 4 & 4 & 0 & 1 \\
\hline 24 & 04.01 .17 & 83 & 71 & 69 & 2 & 3 & 2 & 0 & 1 \\
\hline 25 & 05.01 .17 & 81 & 68 & 66 & 2 & 3 & 3 & 0 & 1 \\
\hline 26 & 06.01 .17 & 78 & 66 & 64 & 3 & 2 & 2 & 0 & 1 \\
\hline 27 & 07.01 .17 & 76 & 63 & 61 & 2 & 3 & 3 & 0 & 1 \\
\hline 28 & 08.01 .17 & 75 & 62 & 60 & 1 & 1 & 1 & 0 & 1 \\
\hline 29 & 09.01 .17 & 72 & 59 & 57 & 3 & 3 & 3 & 0 & 1 \\
\hline 30 & 10.01 .17 & 70 & 57 & 55 & 2 & 2 & 2 & 0 & 1 \\
\hline 31 & 11.01 .17 & 68 & 55 & 53 & 2 & 2 & 2 & 2.5 & 3 \\
\hline 32 & 12.01 .17 & 70 & 57 & 55 & 0 & 0 & 0 & 0 & 1 \\
\hline 33 & 13.01 .17 & 69 & 56 & 54 & 1 & 1 & 1 & 0 & 2 \\
\hline 34 & 14.01 .17 & 69 & 56 & 54 & 0 & 0 & 0 & 0 & 1 \\
\hline 35 & 15.01 .17 & 67 & 54 & 52 & 2 & 2 & 2 & 0 & 1 \\
\hline 36 & 16.01 .17 & 66 & 53 & 50 & 1 & 1 & 2 & 0 & 1 \\
\hline 37 & 17.01 .17 & 64 & 51 & 48 & 2 & 2 & 2 & 0 & 1 \\
\hline 38 & 18.01 .17 & 63 & 49 & 46 & 1 & 2 & 2 & 0 & 1 \\
\hline 39 & 19.01 .17 & 62 & 48 & 45 & 1 & 1 & 1 & 0 & 1 \\
\hline 40 & 20.01 .17 & 61 & 46 & 42 & 1 & 2 & 3 & 0 & 1 \\
\hline 41 & 21.01 .17 & 61 & 43 & 40 & 0 & 3 & 2 & 0 & 1 \\
\hline 42 & 22.01 .17 & 59 & 41 & - & 2 & 2 & - & 0 & 1 \\
\hline 43 & 23.01 .17 & 57 & 40 & - & 2 & 1 & - & 0 & 1 \\
\hline 44 & 24.01 .17 & 56 & - & - & 1 & - & - & 0 & 1 \\
\hline 45 & 25.01 .17 & 54 & - & - & 2 & - & - & 0 & 2 \\
\hline 46 & 26.01 .17 & 52 & - & - & 2 & - & - & 0 & 1 \\
\hline 47 & 27.01 .17 & 50 & - & - & 2 & - & - & 0 & 1 \\
\hline 48 & 28.01 .17 & 47 & - & - & 3 & - & - & 0 & 1 \\
\hline 49 & 29.01 .17 & 45 & - & - & 2 & - & - & 0 & 1 \\
\hline 50 & 30.01 .17 & 42 & - & - & 3 & - & - & 0 & 1 \\
\hline 51 & 31.01 .17 & 41 & - & - & 1 & - & - & 0 & 1 \\
\hline 52 & 01.02 .17 & 40 & - & - & 1 & - & - & 0 & 1 \\
\hline \multicolumn{2}{|c|}{ Average } & - & - & - & 1.6 & 1.95 & 2.05 & - & 1 \\
\hline
\end{tabular}

* 1 - clear sky; 2 - cloudy; 3 - rainy

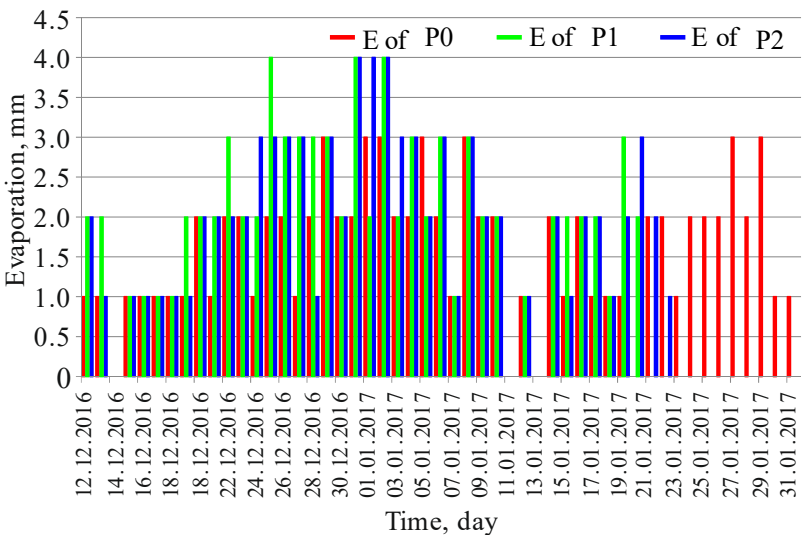

\section{Figure 7. Evaporation curves for brines in P0, P1 and P2}

Therefore, we received a gain of 9 days thanks to the $\mathrm{SM}$, and 11 days thanks to the GM1, hence a rate of the crystallization process optimization was about $17 \%$ for the $\mathrm{P} 2$ and $21 \%$ for the $\mathrm{P} 1$.

During this test, we conducted hourly monitoring of the air and brine temperatures from 09:00 to 16:00 on 28.12.2016. The results are shown in Table 5.

Table 5. Hourly monitoring of brines and air temperatures

Air Tempera- Tempera- Tempera- Meteorolo-

Time tempera- ture of $\mathrm{P} 0$, ture of $\mathrm{P} 1$, ture of $\mathrm{P} 2$, gical obser-

\begin{tabular}{cccccc} 
& ture,${ }^{\circ} \mathrm{C}$ & ${ }^{\circ} \mathrm{C}$ & ${ }^{\circ} \mathrm{C}$ & ${ }^{\circ} \mathrm{C}$ & vation \\
\hline $9: 00$ & 25.5 & 11.5 & 11.5 & 11.5 & Clear sky \\
$10: 00$ & 31.0 & 12.0 & 13.5 & 13.0 & Clear sky \\
$11: 00$ & 32.5 & 17.0 & 18.0 & 17.0 & Cloudy \\
$12: 00$ & 33.5 & 17.5 & 19.5 & 18.5 & Clear sky \\
$13: 00$ & 35.5 & 18.5 & 20.0 & 19.5 & Clear sky \\
$14: 00$ & 33.5 & 19.0 & 21.0 & 21.0 & Clear sky \\
$15: 00$ & 32.0 & 19.5 & 21.0 & 21.0 & Clear sky \\
$16: 00$ & 28.5 & 19.0 & 20.0 & 20.5 & Clear sky \\
\hline
\end{tabular}

The curves of the brine temperatures in $\mathrm{P} 1, \mathrm{P} 2$ in comparison with the brine in P0 (Fig. 8) suggest that there is a gap symmetrically from 1 to $3 \mathrm{C}^{\circ}$ caused by the influence of the solar rays reflection thanks to the plane mirror. Their increase is based on the elevation of the air temperature curve.

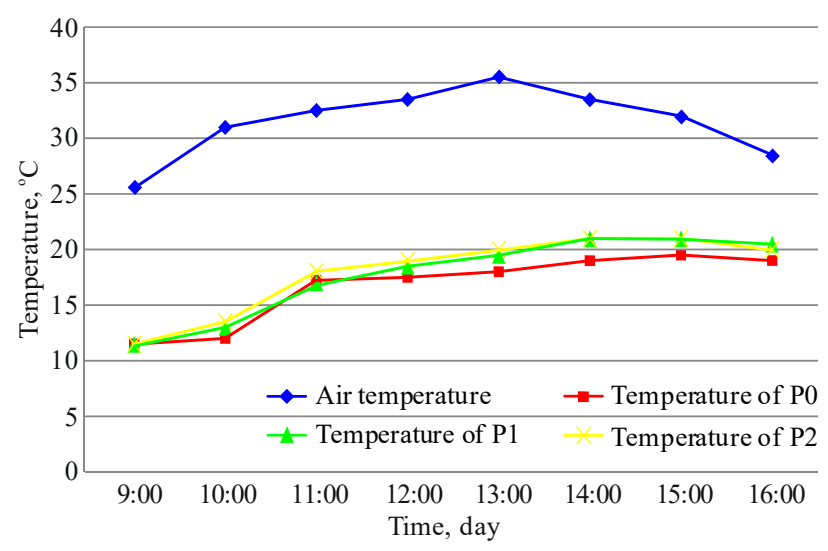

Figure 8. Temperature curves for brines and air 


\subsection{Chemical analysis of crystallized salt}

The crystallized salt samples obtained from the test pans were analyzed at the laboratory of unit SME and recorded in the following summary Table 6 . It is found that almost all chemical analyzes of salt in the pans are identical where the halite content is between $95.80 \%$ and $95.97 \%$. So it can be said that solar radiation has no influence on the quality of the salt.

Table 6. Chemical analysis of crystallized salt in P0, P1 and P2

\begin{tabular}{lcccc}
\hline \multirow{2}{*}{ Designation } & Chemical & \multicolumn{3}{c}{ Analysis Results \% } \\
\cline { 3 - 5 } & Formula & $\mathrm{P} 2$ & $\mathrm{P} 1$ & $\mathrm{P} 0$ \\
\hline Insoluble residue & $\mathrm{RI}$ & 0.4850 & 0.4956 & 0.385 \\
Calcium & $\mathrm{Ca}^{+2}$ & 0.0754 & 0.0674 & 0.07000 \\
Magnesium & $\mathrm{Mg}^{+2}$ & 0.7941 & 0.8306 & 0.7800 \\
Sulphate & $\mathrm{SO}_{4}^{-2}$ & 0.4820 & 0.5226 & 0.4800 \\
Carbonate & $\mathrm{CO}_{3}$ & 0.0000 & 0.0000 & 0.0000 \\
Bicarbonate & $\mathrm{HCO}_{3}$ & 0.0000 & 0.0000 & 0.0000 \\
Calcium Sulfate & $\mathrm{CaSO}_{4}$ & 0.2560 & 0.2288 & 0.2377 \\
Magnesium sulphate & $\mathrm{MgSO}_{4}$ & 0.6310 & 0.706 & 0.6488 \\
Sodium sulphate & $\mathrm{Na}_{2} \mathrm{SO}_{4}$ & 0.0000 & 0.0000 & 0.0000 \\
Calcium Chloride & $\mathrm{CaCL}_{2}$ & 0.0000 & 0.0000 & 0.0000 \\
Magnesium chloride & $\mathrm{MgCL}_{2}$ & 0.8204 & 0.9041 & 0.7543 \\
Sodium chloride & $\mathrm{NaCL}^{2}$ & 95.8075 & 95.6655 & 95.9783 \\
\hline
\end{tabular}

\section{CONCLUSIONS}

With low humidity and favorable wind speed, the test conducted on Chott Merouane suggests that there is an influence of excess temperature generated by the concentration of solar rays on the surface of brine in the pans, accelerated evaporation rate due to the reduced length of exposure compared to the control pan. Then, optimization of salt crystallization by solar energy comprises:

$-17 \%$, if the mirror surface represents $31.49 \%$ of the brine surface in the pan;

$-21 \%$, if the mirror surface represents $77 \%$ of the brine surface in the pan.

This optimization was carried out during December and January. It means that in winter, the coldest season in Algeria, the sky at times is covered with clouds which hinders the performance of mirrors in comparison with the spring and summer seasons.

\section{ACKNOWLEDGEMENTS}

The authors are gratefully acknowledging the Badji Mokhtar University and Larbi Tebessi for provided the assistance to carry out this scientific study.

\section{REFERENCES}

Abdel-Aal, H.K., \& Al-Naafa, M.A. (1993). Enhanced evaporation of saline water in multipurpose solar desalination units. Desalination, 93(1-3), 557-562. https://doi.org/10.1016/0011-9164(93)80130-f

Ballais, J.L. (2010). Des oueds mythiques aux rivières artificielles: l'hydrographie du Bas-Sahara Algérien. PhysioGéographie Physique et Environnement, (4), 107-127. https://doi.org/10.4000/physio-geo.1173

Bounouala, M., Remli, S., \& Talhi, K. (2015). Geochemical and mineralogical study for purpose of crystallization pro- cess optimization by solar energy: in the case of chott Merouane El-Oued Algeria. In 5th Maghreb Conference on Desalination and Water Treatment. Hammamet, Tunisia: Global Water Jobs.

Diaz, R.B.F., Stewart, S.W., \& Brownson, J.R.S. (2012). Use of concentrated solar thermal energy systems to enhance sea salt production in southern Spain. In World Renewable Energy Forum. Denver, Colorado, United States: American Solar Energy Society.

Enasel. (2011). Plan d'exploitation et de valorisation du sel solaire. Rapport inédit. Chott Merouane El-Oued, Algérie: Ministère de L'Energie et des Mines.

Hacini, M., Kherici, N., \& Oelkers, E.H. (2008). Mineral precipitation rates during the complete evaporation of the Merouane Chott ephemeral lake. Geochimica et Cosmochimica Acta, 72(6), 1583-1597.

https://doi.org/10.1016/j.gca.2008.01.019

Hadj Ammar, M.A., Benhaouaet, B., \& Balghouthi, M. (2015). Simulation of tubular adsorber for adsorption refrigeration system powered by solar energy in sub-Sahara region of Algeria. Energy Conversion and Management, (106), 31-40.

Horri, B., Nan, C., Chen, X., \& Wang, H. (2014). Modelling of solar evaporation assisted by floating light-absorbing porous materials. Current Environmental Engineering, 1(2), 73-81. https://doi.org/10.2174/2212717801666141021001740

Huang, H., Shi, M., \& Ge, X. (1999). The effect of a black insulation sheet on the evaporation rate from a shallow salt pond. International Journal of Energy Research, 23(1), 31-39. https://doi.org/10.1002/(sici)1099-114x(199901)23:1<31:: aid-er449>3.0.co;2-f

Kasedde, H., Lwanyaga, J.D., Kirabira, J.B., \& Bäbler, M.U. (2015). Optimization of solar energy for salt extraction from lake Katwe, Uganda. Global NEST Journal, 16(6), $1152-1168$

https://doi.org/10.30955/gnj.001367

Mahowald, N.M., Bryant, R.G., del Corral, J., \& Steinberger, L. (2003). Ephemeral lakes and desert dust sources. Geophysical Research Letters, 30(2), 46(1)-46(4).

https://doi.org/10.1029/2002gl016041

Tamimi, A., \& Rawajfeh, K. (2007). Lumped modeling of solar-evaporative ponds charged from the water of the Dead Sea. Desalination, 216(1-3), 356-366. https://doi.org/10.1016/j.desal.2006.11.022

Unesco. (1972). Etude des ressources en eau du Sahara Septentrional. Rapports sur les résultats $\mathrm{du}$ projet conclusion et recommandations. Paris: Unesco édition.

Yettou, F., Malek, A., Haddadi, M., \& Gama1, A. (2009). Etude comparative de deux modèles de calcul du rayonnement solaire par ciel clair en Algérie. Revue des Energies Renouvelables, 12(2), 331-346.

Zhang, Y.Z., Ge, X.S., Li, Y.F., \& Li, C.D. (1993). Mathematical simulation of evaporating brine by solar radiation for the production of salt. Journal of Thermal Science, 2(2), 143-151. https://doi.org/10.1007/bf02718270

Zeng, Y., Yao, J., Horri, B.A., Wang, K., Wu, Y., Li, D., \& Wang, H. (2011). Solar evaporation enhancement using floating light-absorbing magnetic particles. Energy \& Environmental Science, 4(10), 4074-4078. https://doi.org/10.1039/c1ee01532j 


\section{ОПТИМІЗАЦІЯ ПРОЦЕСУ КРИСТАЛІЗАЦІЇ СОЛІ ЗА РАХУНОК СОНЯЧНОЇ ЕНЕРГІЇ ІЗ ВИКОРИСТАННЯМ ВІДБИВАЮЧИХ ДЗЕРКАЛ (НА ПРИКЛАДІ ШОТТ-МЕРУАН, ЕЛЬ-КУЕД, ПІВДЕННО-СХІДНИЙ АЛЖИР)}

\section{С. Ремлі, М. Боуноуала, І. Роуайгуйа, А. Бенселхуб}

Мета. Оптимізація умов збору шару кристалізованої солі на солончаках озер Меруан і Мельгир у південносхідному Алжирі на основі прискорення процесів іiї випаровування й кристалізації із використанням системи плоских дзеркал, відбиваючих сонячну радіацію на поверхню, що випаровується.

Методика. Для досягнення поставленої мети було виконано моніторинг змін кліматичних параметрів 31975 по 2010 роки. Розроблено дослідну установку поблизу озера Меруан, що складається з чанів, заповнених розсолом товщиною 120 мм кожен, розміщених у землі та оснащених плоскими простими дзеркалами і дзеркалами, що захоплюють сонячні промені й відбивають їх до поверхні розсолу. Випробування проводилися в період 3 12.12.2016 по 1.02.2017. 3 09:00 ранку до 16:00 вечора дзеркала рухались за сонцем за допомогою регулювання кутів до положення сонця (азимут і висота). Щодня реєструвалася швидкість вітру, вологість і особливо випаровування, що було зроблено з використанням лінійки, закріпленої у стінці кожного чану.

Результати. Встановлено, що для утворення кристалізованого сольового шару завтовшки 40 мм, що підходить для збору, в чанах P1 і P2, оснащених плоскими простими дзеркалами (SM), потрібно 52 дні, а в чанах 3 дзеркалами Р0, що захоплюють сонячні промені й відбивають їх до поверхні розсолу (GM1) - 41 і 43 дня відповідно. Приріст у 9 днів отриманий завдяки використанню SM і 11 днів - GM1, а швидкість оптимізації процесу кристалізації склала $17 \%$, якщо поверхня дзеркала становить $31.49 \%$ поверхні розсолу в чані (Р2) і $21 \%$, якщо поверхня дзеркала становить 77\% поверхні розсолу в чані (Р2). Визначено, що майже всі хімічні аналізи солі в чанах ідентичні, вміст галіту становить 95.80 - 95.97\%, тобто сонячна радіація не впливає на якість солі.

Наукова новизна. Доведено, що процес випаровування та кристалізації солі залежать від розміру поверхні відбиваючого дзеркала, що дозволяє отримати шар м’якої солі, легковидобувної у зимовий період.

Практична значимість. Використання дзеркал, що відбивають сонячну радіацію в солезбірних чанах установки на солончаках озер Меруан і Мельгір, покращує кількісні, якісні та економічні показники, а також дозволяє звести до мінімуму задіяні сільськогосподарські території.

Ключові слова: Ель-Куед, озеро Меруан, сонячна енергія, оптимізаиія, випаровування, кристалізаиія солі

\section{ОПТИМИЗАЦИЯ ПРОЦЕССА КРИСТАЛЛИЗАЦИИ СОЛИ ЗА СЧЕТ СОЛНЕЧНОЙ ЭНЕРГИИ С ИСПОЛЬЗОВАНИЕМ ОТРАЖАЮЩИХ ЗЕРКАЛ (НА ПРИМЕРЕ ШОТТ-МЕРУАН, ЭЛЬ-КУЭД, ЮГО-ВОСТОЧНЫЙ АЛЖИР)}

\section{С. Ремли, М. Боуноуала, И. Роуайгуйа, А. Бенселхуб}

Цель. Оптимизация условий сбора слоя кристаллизованной соли на солончаках озер Меруан и Мельгир в юго-восточном Алжире на основе ускорения процессов ее испарения и кристаллизации с использованием системы плоских зеркал, отражающих солнечную радиацию на испаряющуюся поверхность.

Методика. Для достижения поставленной цели был выполнен мониторинг за изменениями климатических параметров с 1975 по 2010 годы. Смонтирована опытная установка вблизи Chott Merouane, состоящая из чанов, заполненных рассолом толщиной 120 мм каждый, размещенных в земле, оснащенных плоскими простыми зеркалами и зеркалами, захватывающими солнечные лучи и отражающими их к поверхности рассола. Испытание проводилось в период с 12.12.2016 по 1.02.2017. С 09:00 утра до 16:00 вечера зеркала следовали за движением солнца с помощью регулировки углов к положению солнца (азимут и высота). Ежедневно регистрировалась скорость ветра, влажность и особенно испарение, что было сделано с использованием линейки, закрепленной в стенке каждого чана.

Результаты. Установлено, что для образования кристаллизованного солевого слоя толщиной 40 мм, подходящего для сбора, в чанах P1 и Р2, оснащенных плоскими простыми зеркалами (SM), потребовалось 52 дня, а в чанах с зеркалами Р0, захватывающими солнечные лучи и отражающими их к поверхности рассола (GM1) - 41 и 43 дня соответственно. Прирост в 9 дней получен благодаря использованию SM и 11 дней - GM1, а скорость оптимизации процесса кристаллизации составила $17 \%$, если поверхность зеркала представляет собой $31.49 \%$ поверхности рассола в чане (Р2) и $21 \%$, если поверхность зеркала составляет $77 \%$ поверхности рассола в чане (Р2). Определено, что почти все химические анализы соли в чанах идентичны, содержание галита составляет $95.80-95.97 \%$, то есть, что что солнечная радиация не влияет на качество соли.

Научная новизна. Доказано, что процесс испарения и кристаллизации соли зависит от размера поверхности отражающего зеркала, что позволяет получить слой мягкой соли, легкодобываемый в зимний период.

Практическая значимость. Использование зеркал, отражающих солнечную радиацию в солесборных чанах установки на солончаках озер Меруан и Мельгир, улучшает количественные, качественные и экономические показатели, а также позволяет свести к минимуму задействованные сельскохозяйственные территории.

Ключевые слова: Эль-Куэд, озеро Меруан, солнечная энергия, оптимизация, испарение, кристаллизаџия соли 


\section{ARTICLE INFO}

Received: 23 March 2018

Accepted: 28 August 2018

Available online: 21 September 2018

\section{ABOUT AUTHORS}

Samir Remli, PhD Student of the Mining Engineering Department, Université Larbi Tébessi, Route de Constantine, 12002, Tébessa, Algeria. E-mail: samir.remli@yahoo.com

Mohamed Bounouala, Doctor of Philosophy, Professor of the Laboratory of Valorization of Mining Resources and Environment, Badji Mokhtar University, B.P.12, 23000, Annaba, Algeria. E-mail: Bounouala_fr@yahoo.fr

Issam Rouaiguia, PhD Student of the Laboratory of Valorization of Mining Resources and Environment, Badji Mokhtar University, B.P.12, 23000, Annaba, Algeria. E-mail: rouaiguia.issam@gmail.com

Aissa Benselhoub, Doctor of Philosophy, Senior Researcher of the Department of Ecology and Environment Protection, State Agrarian and Economic University, 25 Serhiia Yefremova St, 49027, Dnipro, Ukraine. E-mail: bensel$\underline{\text { houb@yahoo.fr }}$ 